Kong. Res. J. 1(1) : 95-99, 2014

Kongunadu Arts and Science College, Coimbatore

\title{
ANTIOXIDANT POTENTIAL DETERMINATION OF PIPER BETLE AND CISSUS QUADRANGULARIS
}

\author{
Jayavel Chinthamani and Naganathan Srinath* \\ Department of Biotechnology, Kongunadu Arts and Science College, Coimbatore. \\ *E-mail: sri7486@gmail.com
}

\begin{abstract}
India has vital deposit of various herbs and is used in many parts of the country as traditional medicinal treatment like Ayurveda, Unani, Siddha and Homeopathy. With increasing problems of side effects related to chemical drug usages and increasing activity of over drug usages has led to multidrug resistant organisms. In this research we focused on using the plant sources like Piper betle leaves and Cissus quadrangularis stems for understanding their antioxidant scavenging activity. We have extracted the vital compounds using cold percolation method and the methanolic extract was chosen for various antioxidant activity like DPPH, ABTS', FRAP, Hydrogen peroxide and hydroxyl radical scavenging activity. We have found that both the plant extracts showed higher activity and $\mathrm{IC}_{50}$ value for both the extracts in all the tests showed nearly $60 \mu \mathrm{g} \mathrm{mL}^{-1}$ and the graph was plotted using the percentage of inhibition scavenging activity vs the concentration taken for each plant extracts.
\end{abstract}

Keywords: Piper betle, Cissus quadrangularis, DPPH•, ABTS•+, FRAP, Hydrogen peroxide and hydroxyl radical.

\section{INTRODUCTION}

India is a country with vital deposit of various herbs and people utilize these herbs in their food recipes as spices or as vegetable leaves from time immemorial. The World Health Organization (WHO) estimates that plant or their extracts are used in the traditional folk medicine and used nearly by $80 \%$ of the world population (WHO report, 2009). With an increase rate of over exposure towards various antibiotics has created an environment of multidrug resistance microbes such as Escherichia coli, Klebsiella pneumoniae, Aeromonas sp., Mycobacterium tuberculosis, M. leprae, Candida sp., etc. (Waters and Basseler, 2005). This has made the scientists to explore new drugs either using plant sources like medicinal herbs or their parts or chemical sources. Due to the concern related to the side effects by the usages of chemical drugs made a shift in the path of drug usages and caused the public to use herbal medicinal sources for the treatment like Ayurveda, Siddha, Unani and Homeopathy.

In the current research we have chosen Piper betle and Cissus quadrangularis as the source with medicinal property for our research. Before evaluating any medicinal plant, it is essential to understand its antioxidant potential because there are various free radicals released by our body and by various products intake (Abrahim et al., 1993; Gupta and Ray, 2004; Kumar et al., 2010; Arawwala et al., 2011). It has also been found that these free radicals remain as an adjuvant in causing cancer like breast cancer. This causes various trouble related to gastric problems as well as imbalance due to free radicals. We have aimed to understand the scavenging potential of these plants as they are commonly used in India as a source for treating gastric diseases and acidity problems in various parts of South India as well as in tribal areas.

\section{MATERIALS AND METHODS}

\subsection{Collection of herbal plants}

Piper betle leaves and Cissus quandrangularis stems were collected from Tirupur flower market and subjected for plant authentication at Botanical Survey of India, Coimbatore, Tamil Nadu.

\subsection{Processing of Plant leaves and stem using cold percolation method}

The plant leaves and stems were processed using cold percolation method as described by Adonizio et al. (2008). The cold percolation method helps to avoid the medicinal property of any medicinal plant. The plant leaves and stems were stored in dark for a period of 3 weeks and were powdered. The powders of plant leaves and stem was sieved and stored in dark bottle. About $3 \mathrm{~g}$ of powdered plant leaves and stem were separately weighed and added to $30 \mathrm{ml}$ of different solvents in increasing order of polarity such as petroleum ether, chloroform, ethanol, hexane, methanol and distilled water. They were kept in shaking at $200 \mathrm{rpm}$ for 3 days and the extraction was done using muslin cloth. The filtrate was evaporated in dark and scrapped 
and stored in dark bottle. It was subjected to antioxidant scavenging activity and subjected for future research against pathogens.

2.3. Evaluating the various antioxidant properties of extracted $P$. betle and $C$. quadrangularis by in vitro free radical scavenging activity

\subsubsection{DPPH・ scavenging activity}

The 2,2-diphenyl-1picryl hydrazyl (DPPH) scavenging activity of $P$. betle and $C$. quandrangularis is performed using the method described by Blois, in 1995. Various concentrations of samples were taken and as standard Vitamin $\mathrm{C}$ were used in different test tubes. The volume was adjusted to $500 \mu \mathrm{L}$ by adding methanol. About $5 \mathrm{~mL}$ of $0.1 \mathrm{mM}$ methanolic solution of DPPH was added to these test tubes and vortexed. The tubes were allowed to stand at room temperature for $20 \mathrm{~min}$. The control was prepared as above without any extract and methanol was used for the baseline correction. Changes in the absorbance of the samples were measured at 517 $\mathrm{nm}$. The percentage of inhibition radical scavenging activity was measured by the formula:

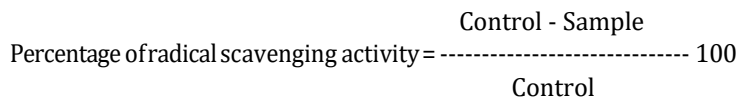

The percentage inhibition vs. concentration was plotted and the concentration required for $50 \%$ inhibition of radicals was expressed as $\mathrm{IC}_{50}$ value.

\subsubsection{ABTS $^{\bullet+}$ radical scavenging activity}

The test was based on the relative activity of antioxidants to quench the radical cation ABTS $\left(2,2^{\prime}-\right.$ azino-bis(3-ethylbenzothiazoline-6-sulphonic acid)+ was done using the method described by $\operatorname{Re}$ et al. (1999). The reaction was initiated by the addition of $1.0 \mathrm{~mL}$ of diluted ABTS to $10 \mu \mathrm{L}$ of different concentration of extract with high antibiofilm activity of the sample or $10 \mu \mathrm{l}$ of methanol serve as control. The absorbance was read at $734 \mathrm{~nm}$. Percentage inhibition was calculated by the formula

$$
\begin{gathered}
\text { Control }- \text { Sample } \\
\text { Percentage of radical scavenging activity }= \\
\text { Control }
\end{gathered}
$$

\subsubsection{Hydrogen Peroxide scavenging activity}

The hydrogen peroxide scavenging activity was measured in terms of a decrease in the absorbance as $230 \mathrm{~nm}$ in spectrophotometer using the method described by Ruch et al. (1989). A solution of $\mathrm{H}_{2} \mathrm{O}_{2}$ was prepared in phosphate buffer. $\mathrm{H}_{2} \mathrm{O}_{2}$ concentration was determined using spectrophotometer from its absorption at $230 \mathrm{~nm}$. Various concentrations of plant extracts were added to $\mathrm{H}_{2} \mathrm{O}_{2}$ and incubated for $10 \mathrm{~min}$. The absorbance at
$230 \mathrm{~nm}$ was determined against a blank containing phosphate buffer without $\mathrm{H}_{2} \mathrm{O}_{2}$. The percentage of scavenging of $\mathrm{H}_{2} \mathrm{O}_{2}$ and standard compound Vitamin $\mathrm{C}$ was calculated using the formula:

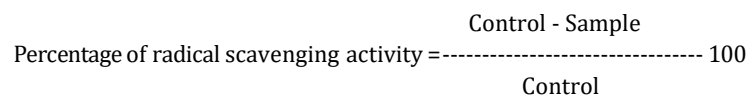

\subsubsection{Hydroxyl radical scavenging activity}

Hydroxyl radicals were generated from ferrous ammonium sulphate and EDTA were determined against the scavenging activity of the plant extracts using the method described by Klein et al. (1991). Various concentration of plant extracts were added with $1 \mathrm{~mL}$ of iron-EDTA solution $(0.13 \%$ ferrous ammonium sulphate and $0.26 \%$ EDTA), $0.5 \mathrm{~mL}$ of EDTA solution (0.018\%), and $1 \mathrm{ml}$ of DMSO (0.85\% $\mathrm{v} / \mathrm{v}$ in $0.1 \mathrm{M}$ phosphate buffer, $\mathrm{pH}$ 7.4). The reaction was initiated by adding $0.5 \mathrm{ml}$ of ascorbic acid $(0.22$

$\%$ ) and incubated at 80 to $90{ }^{\circ} \mathrm{C}$ for $15 \mathrm{~min}$ in a water bath. After incubation the reaction was terminated by the addition of $1 \mathrm{~mL}$ of ice-cold tri-chloro acetic acid (TCA) (17.5\% w/v). $3 \mathrm{ml}$ of Nash reagent was added and left at room temperature for $15 \mathrm{~min}$. The reaction mixture without sample was used as control. The intensity of the color formed was measured spectrophotometrically at $412 \mathrm{~nm}$ against reagent blank. The percentage of hydroxyl radical scavenging activity is calculated by the following formula.

Control - Sample
Percentage of radical scavenging activity $=$
$-\mathbf{y}^{-}$Control

\subsubsection{Ferric reducing antioxidant power (FRAP) assay}

The total antioxidant potential of sample was determined using ferric reducing antioxidant power (FRAP) using the method described by Benzie and Strain, 1996. The stock solution of $10 \mathrm{mM} \mathrm{2,} \mathrm{4,} \mathrm{6-}$ tripyridyl-s-triazine (TPTZ) in $40 \mathrm{mM} \mathrm{HCl}, 20 \mathrm{~mm}$ $\mathrm{FeCl}_{3}, 6 \mathrm{H}_{2} \mathrm{O}$ and $0.3 \mathrm{M}$ acetate buffer ( $\left.\mathrm{pH} 3.6\right)$ were prepared. The FRAP reagent contained $2.5 \mathrm{ml}$ TPTZ solution, $2.5 \mathrm{~mL}$ ferric chloride solution and $25 \mathrm{~mL}$ acetate buffer. It was freshly prepared and warmed to $37{ }^{\circ} \mathrm{C} .900 \mu \mathrm{L}$ FRAP reagent were mixed with 90 $\mu \mathrm{L}$ water and $30 \mu \mathrm{L}$ test sample/ethanol/distilled water/standard antioxidant solution. The reaction mixture was then incubated at $37{ }^{\circ} \mathrm{C}$ for $30 \mathrm{~min}$ and the absorbance was recorded at $595 \mathrm{~nm}$. An intense blue color complex were formed when ferric tripyridyl triazine ( $\left.\mathrm{Fe}^{3+}-\mathrm{TPTZ}\right)$ complex were reduced to ferrous $\left(\mathrm{Fe}^{2+}\right)$ form. The absorption at $540 \mathrm{~nm}$ was recorded. The calibration curve was plotted with absorbance at $595 \mathrm{~nm}$ vs concentration of ferrous sulphate in the range $0.1 \mathrm{mM}$ ethanol solutions. The concentrations of $\mathrm{FeSO}_{4}$ were in turn 
plotted against concentration of standard antioxidants.

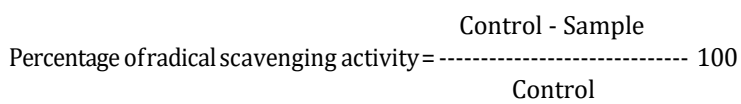

\section{RESULTS AND DISCUSSION}

The collected $P$. betle leaves and $C$. quadrangularis stem were taken to Botanical Survey of India, Coimbatore and authentication no. for the plant is BSI/SRC/5/23/2013-14/Tech./1893. The processing and extraction of the plants leaves and stems were done accordingly and the methanolic extract of both the plants were subjected for further scavenging activity analysis based on the work done by Gupta and Ray (2004).

3.1. Evaluating the various antioxidant properties of extracted Piper betle and Cissus quadrangularis by In vitro free radical scavenging activity

Methanolic extracts of $P$. betle and $C$. quadrangularis were carried out with antioxidant test and identified that the free radical of the extract were found to have high percentage of inhibition against DPPH, ABTS ${ }^{+}$, hydrogen peroxide, hydroxyl and FRAP. Vitamin $C$ served as the standard for all the antioxidant assays carried out in the study and when compared the methanolic extracts of $C$. quadrangularis was higher than $P$. betle. The results were observed to have higher percentage of inhibition for the extracts and the $\mathrm{IC}_{50}$ value was observed as $60 \mu \mathrm{g} / \mathrm{ml}$ in all the tests (Fig. 1, 2, 3, 4, and 5).

This shows that $P$. betle and $C$. quadrangularis has higher scavenging activity as compared with the results of Gupta and Ray (2004) and Kumar et al. (2010). Based on the experimental outcome of Abrahim et al. (1993), the antioxidant activities of the leaves of $P$. betle showed inhibitory effect on the proliferation of the breast cancer cell line, MCF-7. Antioxidant activities were measured using FRAP, DPPH, superoxide anion, nitric oxide and hyroxyl radical scavenging assays was also found to higher as the result obtained in the current research (Abrahim et al., 1993).

\section{CONCLUSION}

This proves that both the plants $P$. betle and C. quadrangularis have higher scavenging activity using the methanolic extract of plant leaves and stems. This shows that these plant extracts can be further studied in future to understand the antibacterial activity as well as can serve as a potent drug in future pharmaceutical research.

\section{ACKNOWLEDGEMENT}

We thank DBT-STAR College scheme, Department of Biotechnology, New Delhi for their financial support and encouraging research in undergraduate level. We thank our management, Kongunadu Arts and Science College, for its infrastructure and laboratory support for this research work.

\section{REFERENCES}

Abraham, R., K. Angel and K. Ron, (1993). Protection of the rat jejunal mucosa against oxidative injury by cationized superoxide dismutase. J. Pharm. Sci. 82(12):1285-1287.

Adonizio A., K. Kok-Fai and M. Kalai, (2008). Inhibition of quorum sensing-controlled virulence factor production in Pseudomonas aeruginosa by South Florida plant extracts. Antimicrob Agents Chemother. 52(1):198-203.

Arawwawala, M., I. Thabrew, L. Arambewela and S. Handunnetti, (2010). Anti-inflammatory activity of Trichosanthese cucumerina Linn. in rats. J. Ethanopharmacol. 131:538-43.

Benzie, I. F. F. and J. J. Strain, (1996). Ferric reducing ability of plasma (FRAP) as a measure of antioxidant power: The FRAP assay. Anal. Biochem. 239: 70-76.

Gupta, P. C., and C. S. Ray (2004). Epidemiology of betel quid usage. Ann. Acad. Med. 33(4):31-36.

Klein S. M., G. Cohen and A. I. Cederbaum, (1991). Production of formaldehyde during metabolism of dimethyl sulphoxide by hydroxyl radical radical generating system. Biochemistry. 20: 6006-6012.

Kumar A., Garg B. R., Rajput G., Chandel D., Muwalia A., Bala I. and Singh Sumeer, (2010). Antibacterial activity and quantitative determination of protein from leaf of Datura stramonium and Piper betle plants. Pharmacophore. 1(3):184-195.

Re R., N. Pelligrini, A. Proteggeenate, M. Yang and C. Rice-Evans, (1999). Antioxidants activity of applying an improved ABTS radical cation decolorisation assay. Free Radic. Biol. Med. 26: 1231-1237.

Ruch R., S. Cheng and J. Klauning, (1989). Prevention of cytoxicity and inhibition of intercellular communication antioxidant catechins isolated from Chinese green tea. Carcinogenesis. 10: 1003-1008.

Waters, C. M. and B. L. Bassler, (2005). Quorum sensing: cell-to-cell communication in bacteria. Annu. Rev.Cell Dev. Biol. 21: 319-346.

WHO survey, (2009). In medicinal plants (Eds. Haq. I.) Hamdard Foundation Press, Karachi, 13. 
Table 1. DPPH· radical scavenging activity.

\begin{tabular}{cccc}
\hline $\begin{array}{c}\text { Concentration } \\
\mu \mathrm{g} / \mathrm{mL}\end{array}$ & $\begin{array}{c}\text { \% of Inhibition of Standard } \\
\text { (Vitamin C) }\end{array}$ & $\begin{array}{c}\text { \% of Inhibition of } \\
\text { Piper betle }\end{array}$ & $\begin{array}{c}\text { \% of Inhibition of Cissus } \\
\text { quadrangularis }\end{array}$ \\
\hline 20 & 8.882 & 8.998 & 10.010 \\
40 & 27.844 & 11.425 & 23.761 \\
60 & 40.119 & 35.288 & 48.230 \\
80 & 58.882 & 47.118 & 75.935 \\
100 & 85.828 & 75.530 & 79.777 \\
\hline
\end{tabular}

Table 2. ABTS ${ }^{\bullet+}$ radical scavenging activity

\begin{tabular}{cccc}
\hline $\begin{array}{c}\text { Concentration } \\
\mu \mathrm{g} / \mathrm{mL}\end{array}$ & $\begin{array}{c}\text { \% of Inhibition of Standard } \\
\text { (Vitamin C) }\end{array}$ & $\begin{array}{c}\text { \% of Inhibition of } \\
\text { Piper betle }\end{array}$ & $\begin{array}{c}\text { \% of Inhibition of Cissus } \\
\text { quadrangularis }\end{array}$ \\
\hline 20 & 7.280 & 12.899 & 7.371 \\
40 & 35.760 & 29.852 & 25.921 \\
60 & 53.961 & 50.859 & 53.961 \\
80 & 76.552 & 73.710 & 76.552 \\
100 & 89.186 & 76.289 & 89.186 \\
\hline
\end{tabular}

Table 3. Hydroxyl radical scavenging activity

\begin{tabular}{cccc}
\hline $\begin{array}{c}\text { Concentration } \\
\mu \mathrm{g} / \mathrm{mL}\end{array}$ & $\begin{array}{c}\text { \% of Inhibition of Standard } \\
\text { (Vitamin C) }\end{array}$ & $\begin{array}{c}\text { \% of Inhibition of } \\
\text { Piper betle }\end{array}$ & $\begin{array}{c}\text { \% of Inhibition of Cissus } \\
\text { quadrangularis }\end{array}$ \\
\hline 20 & 6.216 & 1.722 & 8.151 \\
40 & 23.280 & 15.843 & 18.254 \\
60 & 57.407 & 29.735 & 34.902 \\
80 & 79.761 & 62.571 & 53.960 \\
100 & 89.682 & 75.545 & 69.345 \\
\hline
\end{tabular}

Table 4. Hydrogen peroxide scavenging activity

\begin{tabular}{cccc}
\hline $\begin{array}{c}\text { Concentration } \\
\mu \mathrm{g} / \mathrm{mL}\end{array}$ & $\begin{array}{c}\text { \% of Inhibition of Standard } \\
\text { (Vitamin C) }\end{array}$ & $\begin{array}{c}\text { \% of Inhibition of } \\
\text { Piper betle }\end{array}$ & $\begin{array}{c}\text { \% of Inhibition of Cissus } \\
\text { quadrangularis }\end{array}$ \\
\hline 20 & 16.939 & 18.961 & 9.315 \\
40 & 31.420 & 45.012 & 27.947 \\
60 & 45.264 & 58.779 & 48.062 \\
80 & 58.105 & 66.611 & 58.944 \\
100 & 78.688 & 71.393 & 73.371 \\
\hline
\end{tabular}

Table 5. Ferric Reducing Antioxidant Power Assay (FRAP)

\begin{tabular}{cccc}
$\begin{array}{c}\text { Concentration } \\
\mu \mathrm{g} / \mathrm{mL}\end{array}$ & $\begin{array}{c}\text { OD value at } 595 \mathrm{~nm} \text { of } \\
\text { Standard (Vitamin C) }\end{array}$ & $\begin{array}{c}\text { OD value at } 595 \mathrm{~nm} \text { of } \\
\text { Piper betle }\end{array}$ & $\begin{array}{c}\text { OD value at 595nm of Cissus } \\
\text { quadrangularis }\end{array}$ \\
\hline 20 & 0.18 & 0.26 & 0.198 \\
40 & 0.362 & 0.394 & 0.322 \\
60 & 0.62 & 0.467 & 0.576 \\
80 & 0.713 & 0.519 & 0.622 \\
100 & 0.96 & 0.73 & 0.79 \\
\hline
\end{tabular}


Fig. 1. DPPH radical scavenging activity of $P$. betle and C. quadrangularis

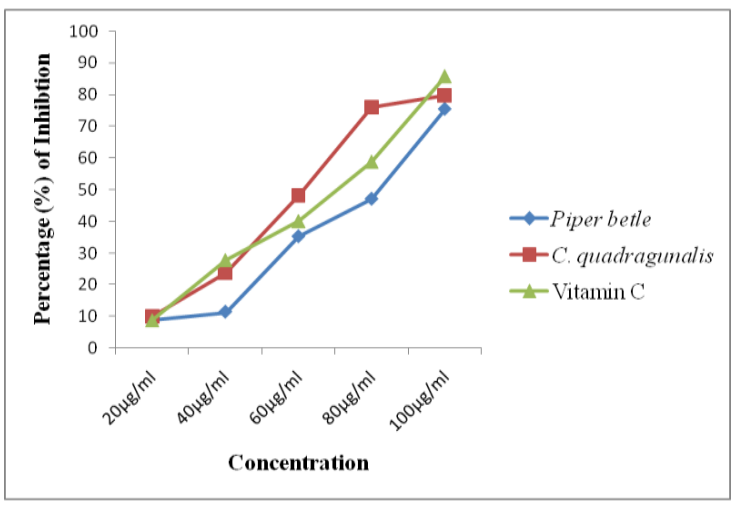

Fig. 2. ABTS ${ }^{+}$radical scavenging activity of $P$. betle and $C$. quadrangularis

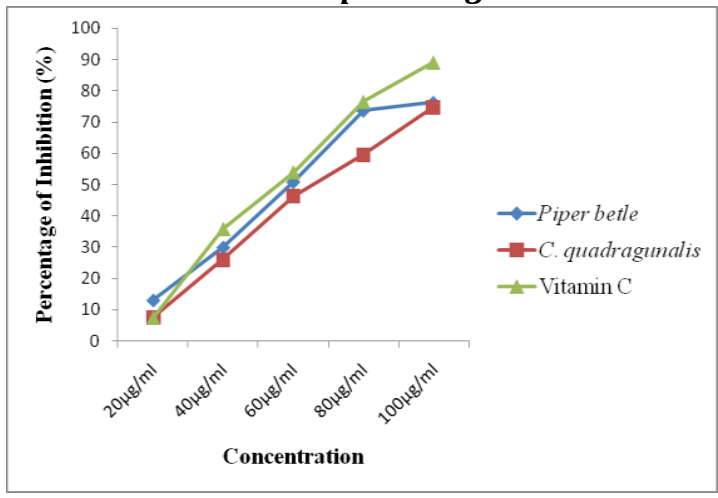

Fig. 3. Hydroxyl radical scavenging activity of $P$. betle and $C$. quadrangularis

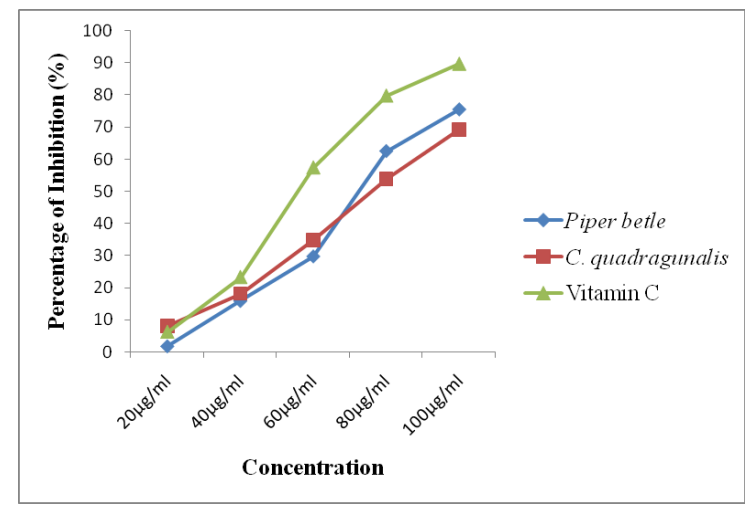

Fig. 4. Hydrogen Peroxide radical scavenging activity of $P$. betle and $C$. quadrangularis

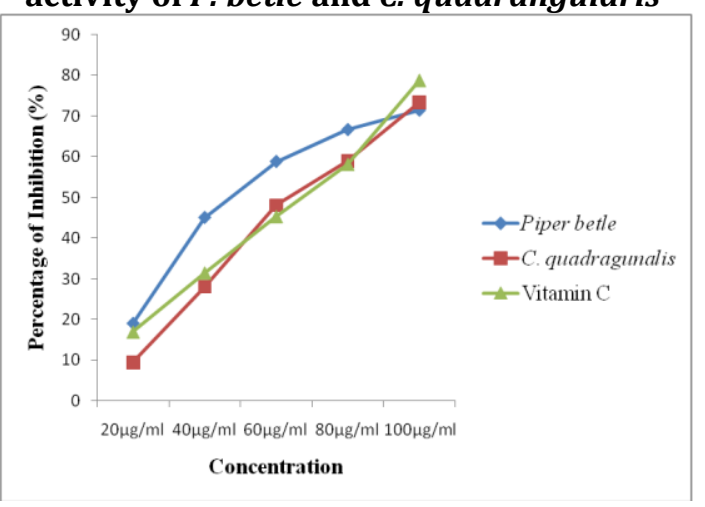

Fig. 5. FRAP radical scavenging activity of $P$. betle and $C$. Quadrangularis

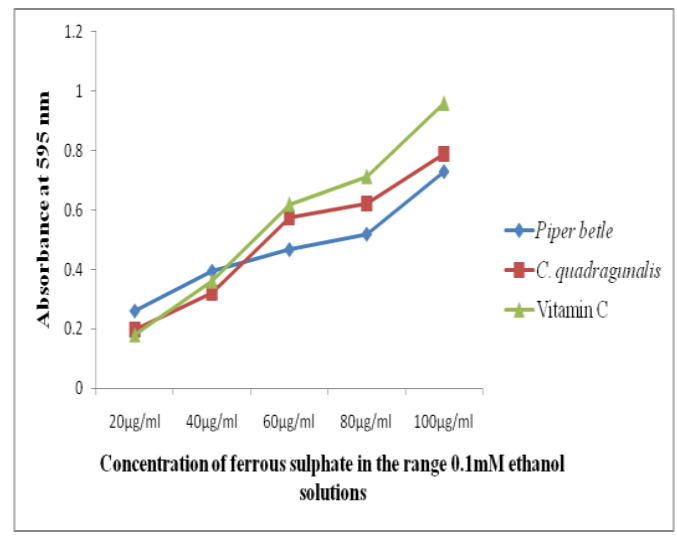

